\title{
Distribution and Evaluation of Shoulder Girdle localized Malignant Musculoskeletal Tumors
}

\section{Omuz Kuşağı Yerleşimli Malign Kas İskelet Sistemi Tümörlerin Dağılımı Ve Değerlendirilmesi}

\author{
Recep Öztürk ${ }^{1}$, Şefik Murat Arıkan², Güray Toğral ${ }^{2}$, Bedii Şafak Güngör² \\ ${ }^{1}$ Polatlı Devlet Hastanesi, Ortopedi Ve Travmatoloji Kliniği, Ankara \\ ${ }^{2}$ Ankara Onkoloji Hastanesi, Ortopedi Ve Travmatoloji Kliniği, Ankara
}

Dergiye Ulaşma Tarihi:23.01.2018 Dergiye Kabul Tarihi:01.03.2018 Doi: 10.5505/aot.2018.30633

\section{ÖZET}

GİRIŞ ve AMAÇ: Kliniğimizde omuz kuşağı yerleşimli malign kas iskelet sistemi tümörü tanısı ile tedavi edilen olguların tanısal dağılımı ve retrospektif incelenmesi amaçlandı

YÖNTEM ve GEREÇLER: Ocak 2001 ile ağustos 2016 yılları arasında omuz çevresi malign tümörü tanısı ile takip ve tedavi edilen 187 vaka retrospektif olarak incelendi.Olgular yaş, cinsiyet, lokalizasyon, histopatolojik tanı ve özellikleri açısından değerlendirildi.

BULGULAR: 187 hastanın 79' u kadın (\% 42.3), 108' i erkek (\%57.7) idi. Hastaların cerrahi zamanındaki yaş ortalaması 47.9 ( 2 - 87 yaş arası) idi. Hastaların 95'i primer tümör, 10’u nüks, 82'si metastaz idi. En sık tumor yerleşim yeri proksimal humerus idi(108 vaka, \%57). Primer tümörler içerisinde en sık tanı ewing's sarkom idi (21 vaka, \%22). Metastatik tümörler içerisinde en s1k görüleni akciğer kanseri metastazı(19 vaka, \%23) idi. İncelemeye alınan 187 hastanın, ortalama tümör boyutu $10.0 \mathrm{~cm} \quad(3-78 \mathrm{~cm}$ arası) idi. TARTIŞMA ve SONUÇ: Malign tümörlerde erken tanı hayati öneme sahiptir. Öykü ve fizik muayenede, lokalizasyona özel yaş, cinsiyet, kemik-yumuşak doku tutulumu, insidans gibi özelliklerin bilinmesi tanıda önemli bir yardımcıdır.

Anahtar Kelimeler: Omuz kuşağı, Skapula, Proksimal Humerus, Allogreft, Ekstremite Koruma, ampütasyon, malign, prognoz

\begin{abstract}
INTRODUCTION: We aimed to retrospectively examine diagnostic distribution of the patients treated with diagnosis of shoulder girdle localized malignant musculoskeletal system in our clinic.

METHODS: A total of 187 patients followed-up and treated shoulder girdle malignant tumor between January 2001 and August 2016 were retrospectively investigated. Patients were evaluated in terms of age, gender, localization, histopathological diagnosis and characteristics.

RESULTS: Out of 187 patients 79 were female (42.3\%) and 108 were male (57.7\%). The mean age of patients at the time of surgery was 47.9 (2-87) years. Of the patients 95 had primary tumor, 10 relaps and 82 metastasis. The most common tumor localization was proximal humerus (108 cases; $57 \%$ ). Among the primary tumors, the most common diagnosis was Ewing's sarcoma (21 cases, 22\%). The most common metastatic tumor was lung cancer metastasis (19 cases, 23\%). The mean tumor size in the 187 patients included was $10.0 \mathrm{~cm}(3-78 \mathrm{~cm})$. DISCUSSION and CONCLUSION: Early diagnosis is vital in malignant tumors. Knowledge of characteristics such as localization specific age, gender, bone-soft tissue involvement and incidence in medical history and physical examination is helpful in the diagnosis.
\end{abstract}

Keywords: Shoulder girdle, Scapula, Proximal Humerus, Allograft, Extremity Protection, amputation, malignant, prognosis

\section{GíRiș}

Omuz kuşağ1; proksimal humerus, skapula, klavikula ve bu yapıları çevreleyen yumuşak dokuları içerir. Üst ekstremite malign tümörlerine s1k rastlanmamakla birlikte, ortopedik incelemelerde yanlış tanı nedeniyle çok ciddi sonuçlar doğurabilen durumlara yol açarlar (1).

Omuz kuşağı yerleşimli bir kitle saptanmas1 halinde, hastanın ileri yaşta olması, ağrı varlığı ve skapula yerleşimli 
olması maligniteyi şiddetle düşündürmelidir (2). Proksimal humerus ve skapula primer sarkomların sık görüldüğü alanlardır $(3,4)$. Bu bölgede çocuklarda osteosarkom ve ewing sarkomu daha s1k görülürken, erişkinlerde kondrosarkoma sik rastlanır (4-6).

Omuz kuşağı, metastatik tümörlerin de sık görüldüğ̈̈ lokalizasyonlardan birisidir. Metastazlarda yaklaşım, ağrının kontrolü ve fonksiyonların yeniden teminini sağlamak olmakla birlikte, genellikle palyatif tedaviler uygulanmaktadır. Metastazlarda, kırık ya da kırık olması olasılığı yüksek olan litik lezyonlarda, hastanın yaşam beklentisi ve yandaş problemleri dikkate alınarak cerrahi planlanır $(1,5,6)$.

Günümüzde, hem kemoterapötik ilaçların neoadjuvan ve adjuvan kullanım protokollerinin gelişmesi, hem protezlerin dizayn, fiksasyon prensipleri gibi alanlardaki güncel gelişmeler, omuz çevresi yerleşimli tümörlerde, geniş cerrahi yaklașımlara ve masif rekonstrüksiyon tekniklerine olanak sağlamaktadır $(2,3,7,11,12)$

$\mathrm{Bu}$ çalışmanın amacı, omuz çevresi yerleşimli malign tümörü olan 187 hastanın, demografik verilerinin retrospektif analizidir.

\section{GEREÇ ve YÖNTEM}

2001 yılı Ocak ayı ile 2016 yılı Ağustos ay1 tarihleri arasinda, hastanemiz ortopedi ve travmatoloji kliniğinde opere edilen, omuz kuşağ1 yerleşimli malign kas iskelet sistemi tümörü olan hastalar, retrospektif olarak incelendi. $79 \operatorname{kadin}(42,2 \%)$ ve 108 erkek $(57,8 \%)$ toplam 187 hasta mevcuttu(resim 1).

105 hasta primer tumor ( 105 hastanın,

95'i primer hastalık ile başvuran hasta iken 10'u nüks hastalık ile başvuran hasta idi), 82 hasta metastatik hastalığa sahipti.

Primer tümöre sahip 105 hastanın histopatolojik tanıları ayrıntılı incelendiğinde; 21'i ewing's sarkom, 21'i osteosarkom, 17'si kondrosarkom, 17'si multiple myeloma, 9'u pleomorfik sarkom, 5' i malign mezenkimal tümör, 3'ü rabdomyosarkom, 2'si sinovial sarkom, 2'si leimyosarkom, 2'si liposarkom, 2'si ekstraskeletal osteosarkom, 1'i angiosarkom, 1'i fibrosarkom, 1'i epiteloid hemangioendotelyoma, 1'i malign periferik sinir k1lıfı tümörü idi.

81 metastatik hastanın, 19'u akciğer karsinomu, 13'ü meme karsinomu, 10'u lenfoma, 9'u renal cell karsinomu, 5'i tiroit karsinomu, 2'si nazofarenks karsinomu, 1'i deri ekinin apokrin duktal adenokarsinomu, 1'i endometrium karsinomu, 1 'i uylukta liposarkom, 1'i uylukta miksofibrosarkom, 1'i humerus distal orijinli ewing's sarkom, 1 'i femur orijinli ewing's sarkom, 1 'i mide ca, l'i lösemi, 1'i rektum ca, 1'i malign melanoma, 1'i özefagus ca, 1'i prostat ca, 1'i pankreas ca, 9'u karsinom metastazı di. 2'si skuamöz cell karsinom idi.

Kliniğimize ilk başvurularında nüks hastalığa sahip hastaların histopatolojik tanıları ayrıntılı incelendiğinde, 3 'ü osteosarkom, 3'ü pleomorfik sarkom, 1'i kondrosarkom, 1'i angiosarkom, 1 ' $\mathrm{i}$ fibrosarkom ve 1 ' $i$ malign mezenkimal tümör idi.

Vakaların takip-tedavi planlanmasında, ortopedist, radyolog, patolog, medikal onkolog ve radyasyon onkoloğunun içinde bulunduğu multidisipliner bir yaklaşım uygulandı. 187 hastanın 42'si insizyonel biopsi ile tanı konulmas1 sonras1, takip ve tedavi planı için ilgili medikal bölümlere konsulte edilerek devredildi (inoperable hastalar ve güncel tedavi yaklaşımı medical tedavi planlanan hastalar, vb.). Bu hastaların 10'u akciğer ca metastazı, 8'i lenfoma, 8'i multiple myeloma metastazı, 5'i primeri bilinmeyen karsinom metastazı, 2'si meme ca metastazı, 2'si tiroit ca metastazı, 1'i uyluk yerleşimli liposarkom metastazı, 1'i lösemi, 1'i ewing sarkom, 1' i osteosarkom, 1'i pancreas ca metastazı, 1'i özefagus ca metastazı, 1'i renal cell ca metastazı idi.

187 hastanın, medikal tedavi için yönlendirilen 42'si haricinde kalan 145 hastaya, hastanemizde nihai cerrahi tedavisi yapıldı. Cerrahi tedavisi yapılan 145 hastanın, 85 'i primer tümöre sahipti, bu hastaların 20'si tanı anında metastatikti, 65 hasta ise tan anında lokalize hastalığa sahipti.

\section{BULGULAR}

Araştırmaya alınan 187 hastanın 79' u kadın (\% 42.2) 108' i erkek iken (\%57.8), nihai cerrahi tedavi uygulanan 145 hastanın 64'ü kadın 81'i erkekti. Cerrahi sırasındaki ortalama yaş 47,9 (2-87 arası) iken, primer tümörlerde 39,7 (2-87 aras1) ve metastatik tümörlerde 58,5 (6-87 aras1) idi (Resim 2).

Tümörlerin omuz kuşağındaki yerleşim 
yerleri ayrıntılı incelendiğinde; 108'inde tümör proksimal humerus yerleşimli, 32'inde omuz çevresi yumuşak dokular, 24'ünde skapula, 17'sinde klavikula, 3'ünde humerus proksimali ve skapula, 3'ünde skapula + klavikula yerleşimli idi (Resim 3).

Nihai cerrahi tedavi uygulanan 145 hastanın 93'ünde tümör humerus proksimal yerleşimli idi. Bu hastaların 15'i primer, 2'si nüks, 1'i metastatik olmak üzere 18 tanesi osteosarkom tan1lı idi. 11'i primer 1'i nüks kondrosarkomdu. 10'u meme ca metastaz1, 9'u primer ewing's sarkom, 1'i ewing's sarkomunun omza metastazı idi. 8'i multiple myeloma, 8'i akciğer ca metastazı, 7'si renal cell ca metastazı, 2'si malign mezenkimal tumor, 2'si nazofarenks ca metastazı, 1'i pleomorfik sarkom, 1'i rabdomyosarkom, 1'i ekstraskeletal osteosarkom, 1'i endometrium ca metastazı, 2'si lenfoma metastazı, 1'i malign melanoma metastazı, 4'ü primeri bilinmeyen karsinom metastazı, 1'i prostat ca metastazı, 1'i rektum ca metastazı, 3'ü tiroit ca metastazı idi.

145 hastanın 24'inde omuz çevresi yumuşak doku malign tümörü mevcuttu.5'i primer, 3'ü nüks pleomorfik sarkom, 2'si primer leimyosarkom, 2'si primer liposarkom, 2'si rabdomyosarkom, 2'si sinovial sarkom, 1'i scc metastazı, 1'i iğsi hücreli malign mezenkimal tümör, 1'i nüks fibrosarkom tanılı idi. Ayrica 1'i primer, 1'i nüks mmt idi. 1'i malign periferik sinir k1lifı tümörü, 1 'i nüks angiosarkom, 1 'i ekstraskeletal osteosarkomdu.

145 hastanın 16'sında malign tümör skapula yerleşimli idi. 6'sı ewing's sarkom, 4 'ü kondrosarkom, 2'si osteosarkom, 1'i meme ca metastazı, 1' i deri ekinin apokrin ductal adenokarsinom metastazı, 1 'i epiteloid hemangioendotelyoma, 1 ' $i$ gastrointestinal system ca metastazı idi. 145 hastanın 8'i klavikula yerleşimli idi.6'sı ewing's sarkom, 1'i kondrosarkom, 1' squamoz cell ca metastazı idi. 145 hastanın 3'ü humerus proksimal + skapula yerleşimli idi. Biri nüks osteosarkom, biri akciğer ca metastazı, biri renal cell ca metastazı idi. 145 hastanın 1'inde tümör skapula+klavikulada idi, bu vakada ise tanı, uyluk yerleşimli miksofibrosarkomun omza metastazı idi. Tanıların yüzdeleri resim 4'de özetlendi (resim 4).

\section{Humerus proksimali yerleşimli tümörü}

olan 93 hastanın yaş ortalaması 45.8 y1, omuz çevresi yumuşak doku yerleşimli tümörü olan 24 hastanın yaş ortalaması 52.0, skapula yerleşimli tümörü olan 16 hastanın yaş ortalaması 36.0, klavikula yerleşimli tümörü olan 8 hastanın yaş ortalaması 34.1, humerus proksimali+ skapula yerleşimli tümörü olan 3 hastanın yaş ortalaması 44.6 y1l, skapula $+k$ klavikula yerleşimli tümörü olan hastanın yaşı ise $87 \mathrm{idi}$.

İncelemeye alınan 187 hastanın, 97'sinde $(\% \quad 51,8)$ hastaların sağ ekstremiteside, 90'inda (\% 48,2), hastaların sol ekstremitesinde tutulum mevcuttu (resim 5). İncelemeye alınan 187 hastanın, ortalama tümör boyutu $10.0 \mathrm{~cm}(3-78 \mathrm{~cm}$ arası) idi. Humerus proksimal yerleşimli tümörlerde ortalama tümör boyutu $10.6 \mathrm{~cm}$, omuz çevresi yumuşak doku malign tümörleri $10.7 \mathrm{~cm}$, skapula $8.6 \mathrm{~cm}$, klavikula $6.0 \mathrm{~cm}$, skapula + klavikula $9.6 \mathrm{~cm}$, humerus proksimal+ skapula $14.0 \mathrm{~cm}$ idi.

Sonuç olarak, 21 hasta osteosarkom tanılı (\%11,2), 21 hasta ewing's sarkom tanılı $(\% 11,2), \quad 17$ hasta kondrosarkom tanılı $(\% 9,0), 17$ hasta multiple myeloma tanilı $(\% 9,0)$, diğer primer tümörler 29 hastayı $(\% 15,5)$ oluşturmaktaydı. 82 hasta $(\% 43,8)$ metastatik tümördü.

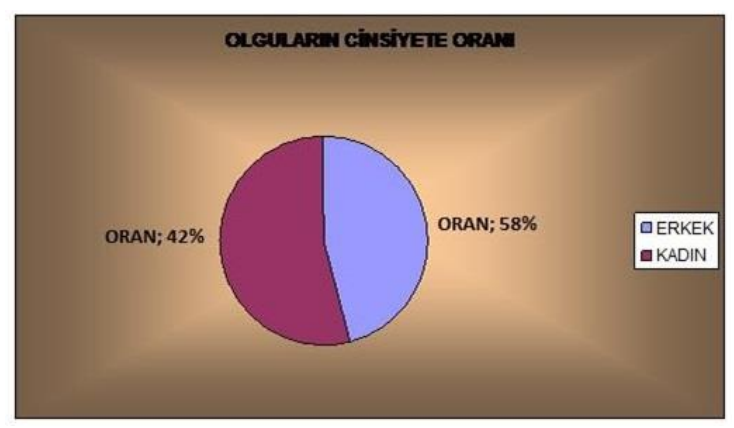

Figür 1. Olguların cinsiyet oranı

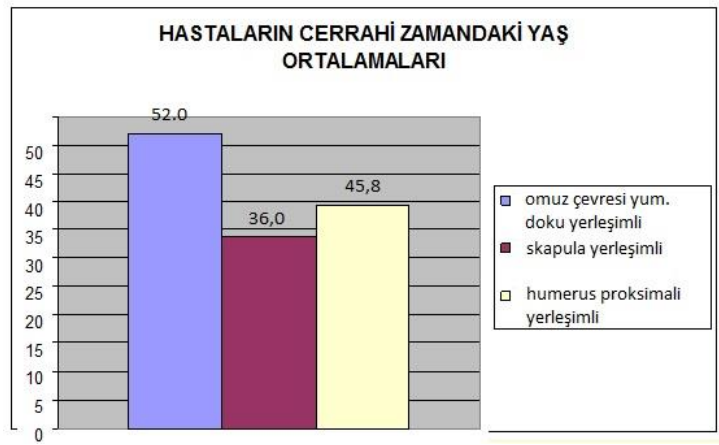

Figür 2. Olguların yaş ortalaması 


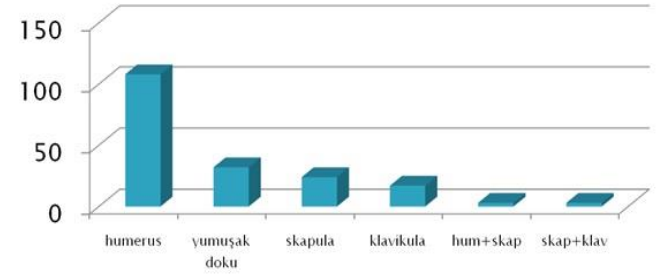

Figür 3. Tümörlerin omuz kuşağındaki yerleşim yerleri

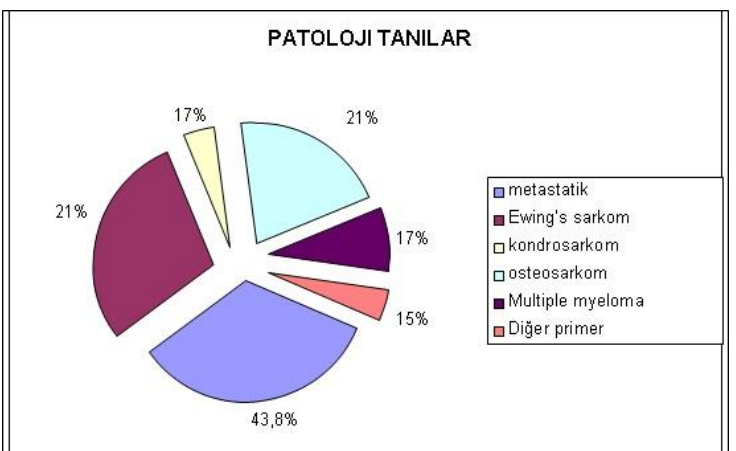

Figür 4. Tanıların yüzdeleri

\section{OLGULARIN EKSTREMITE YÖNLERİ}

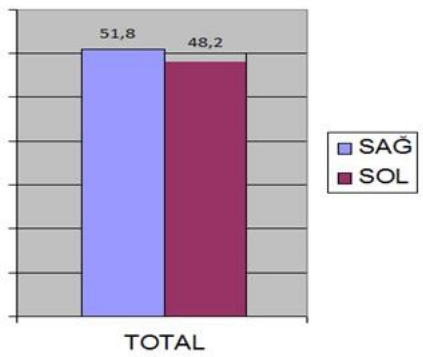

Figür 5. Lateralite

\section{TARTIŞMA}

Omuz kuşağı, proksimal humerus, skapula, klavikula distal 1/3'ü, ve çevresi yumuşak dokuları içerir. Omuz çevresi bütün kemikler, istisnasız olarak, primer veya metastatik kemik tümörü tarafından, yumuşak dokusu da içererek ya da içermeden, tutulabilir (7). Bu çalışmanın amacı, omuz kuşağına yerleşebilen malign tümörlerin özelliklerini literature eşliğinde incelemek ve klinisyenlere güncel pratikte diagnostik rehber oluşturabilmektir.

Omuz kuşağında, en sık kemik tümörü yerleşim yeri proksimal humerustur. İkinci skapula, üçüncü de klavikula takip eder. Ayrıca proksimal humerus, primer kemik malign tümörleri ve karsinomların kemik metastazları için için en sı 3. yerleşim yeridir. (7-8).

Bizim çalışmamızda da literature benzer şekilde en sık yerleşim yeri proksimal humerustu. 187 hastanın 108 'inde tümör proksimal humerus yerleşimli idi. Ancak ikinci sırada 32 vaka ile omuz çevresi yumuşak dokular yeralmakta idi. 24 hastada tümör skapula yerleşimli idi ve skapula en sık üçüncü tümör yerleşim yeriydi. Skapulay1, 17 vaka ile klavikula, takip etmekte idi. $\mathrm{Bu}$ bulgular literatür ile uyumlu bulundu. Benzer şekilde bizim çalışmamızda da, proksimal humerus, skapula ve klavikulada primer malign ve metastatik tümörler görülmüştür. Bizim çalışmamızda 81 erkek, 64 kadın hasta mevcuttu, yani omuz kuşağı malign tümörler erkeklerde fazla görüldü. Bu bulgu literatürle uyumlu idi, Kumar, Meller, Bickels, Taira ve Kiss de çalışmalarında erkek hasta sayısını fazla buldular (9-13).

Omuz kuşağı malign tümörleri cerrahi tedavisi tarihsel perspektifte incelendiğinde, standart prosedür 20.yy'ın ortalarına kadar forequarter amputasyon (skapulotorasik dezartikülasyon) idi. Etkili kemoterapi seçeneklerinin ve daha iyi görüntüleme tekniklerinin keşfedilmesi, tümör davranışlarının daha iyi şekilde anlaşılması, kaybedilen kemik ya da eklem segmentlerinin yerine konabilecek endoprotezlerin kullanıma girmesiyle birlikte sarkomlarda ekstremite koruyucu cerrahi (Limb Salvage) 1970 'li yılların sonlarına doğru oldukça popüler olmuştur.

Francis ve arkadaşları, 1962 yılında, omuz kuşağı malign tümörleri için radikal rezeksiyonu tanımladıkları 5 vakayı içeren seriyi yayınladılar. Yaș ortalaması 36 olan 3 kadın 2 erkek toplam 5 hastada, tümöral tutulumlara göre, amputasyon yerine rezeksiyon teknikleri uyguladılar ve rekonstrüktif bir cerrahi uygulamadılar (14).

Kumar ve ark. 1994 yılında, ekstremite koruyucu cerrahi uyguladıkları omuz çevresi primer malign tümörüne sahip 10 hastanın verilerini yayınladılar. Ortalama yaşı 34 olan 6 erkek 4 kadın hasta mevcuttu, 8 'i kemik 2 'si yumuşak doku tümörü idi. (9). Meller ve ark ise, 1997 yılında, 16 erkek, 14 kadın toplam 30 hastayı içeren, omuz kuşağı malign tümörüne sahip hastaların analizini yayınladılar. 23'ü kemik, 7'si yumuşak doku 
tümörü içeriyordu ve yaş ortalaması 34 (6-80 aras1) idi (10). Bickels ve arkadaşları ise, 2002 y1lında, 17 yıllık süreçte tedavisi düzenlenen omuz çevresi yerleşimli tümöral hastalığa sahip 134 hastanın ekstremite koruyucu cerrahi tedavi sonuçlarını yayınladılar. Yaş ortalamaları 30,1(9-90 aras1) idi. 71 erkek 63 kadın hastayı içeriyordu. 110 hasta primer malign tümör, 12 hasta metastatik tümör, 12 hasta ise benign agresif tümörleri içermekteydi (11). Bizim çalışmamız ise, omuz kuşağ yerleşimli malign tümörler 187 hastayı içermekte idi ve 145 hastaya cerrahi tedavi uyguland. Yukarıda bahsedildiği şekilde, literatürdeki omuz kuşağ1 yerleşimli tümörlerde, yaş ortalamaları değişkendi ve $30-45$ arası değişmekte idi (8-15). Bizim çalışmamızda ise yaş ortalaması 47,9 (2-87 yaş arası) olarak bulundu. Çalışmamızda, literatüre göre daha ileri bir yaş ortalaması bulundu.

Omuz kuşağı yerleşimli malign tümörlerin ayırıcı tanıda akılda tutulması çok önemlidir. Çünkü güncel gelişmeler göstermektedir ki, erken tanıda ekstremite koruyucu cerrahi şansı $\% 90$ ların üzerindedir.

Sonuç olarak, tüm muskulo-skeletal sistem malign tümörlerinin değerlendirilmesinde olduğu gibi omuz kuşağı malign tümörlerinde de, ortopedist, radyolog, patolog, medikal onkolog ve radyasyon onkoloğunun içinde bulunduğu multidisipliner bir yaklaşım gereklidir. Muskulo-skeletal sistem malign tümörlerinin tedavisi, tümörün histopatolojik tipine göre; cerrahi, kemoterapi, radyoterapi veya bunların birlikte kullanıldığı protokollere göre düzenlenmelidir. Yayınlanan güncel çalışmalar, artık amputasyonlar ve negatif cerrahi sinırlarla yapılan ekstremite kurtarıcı girişimler arasında survive yönünden anlamlı bir fark olmadığını kanıtlamıştır. Hastaların prognozunda erken tanı ve uygun yaklaşım hayatidir, erken tanı için, tümörlerin demografik özelliklerinin bilinmesi yol göstericidir.

\section{Çıkar Çatışması: Yok}

\section{REFERANSLAR}

1- Eralp L, Buldu H. Üst ekstremite tümörleri. Hand Microsurg 2013;2:105-114

2- Cleeman E, Auerbach JD, Springfield DS. Tumors of the shoulder girdle: a review of
194 cases. J Shoulder Elbow Surg 2005;14: 460-5.

3- Papagelopoulos PJ, Mavrogenis AF, Total Scapulectomy and Reconstruction Using a Scapular Prothesis. In: Sim FH, Choong PFM, Weber KL. Master Techniques in Orthopaedic Surgery. Philadelphia: Lippincott; 2011.

4- Malawer MM, Wittig J, Proximal Humerus Resection - The Tikhoff-Linberg Procedure and its Modifications. In: Malawer M, Wittig J. Musculoskeletal Cancer Surgery. New York: Kluwer Academic Publishers ; 2004: 519-30.

5- Ozturk R. Kemik ve Yumuşak doku Tümörleri. Atay T, editör. Ortopedi ve Spor Yaralanmaları Asistan Kitab1 (1. Bask1). Ankara Derman Tıbbi Yayıncılık; 2015 :635704.

6- Ozturk R, Arıkan ŞM, Şimşek MA, Özanlağan E, Güngör BŞ.Management of solitary fibrous tumors localized in extremity: case series and a review of the literature. Eklem Hastalik Cerrahisi. 2017;28(2):121-7

7- Kapoor S, Tiwari A, tumors around shoulder. International Orthopaedics (SICOT) (2008) 32:829-834

8- Campanacci M. Bone and Soft Tissue Tumors; Piccin Nuova Libraria Padovaspringer Verlag Wien, New york: 1999. S. 18-20: s909-1909

9- Kumar VP, Satku SK, Mitra AK, Pho RW. Function following limb salvage for primary tumors of the shoulder girdle. 10 patients followed 4 (1-11) years. Acta Orthop Scand. 1994 Feb;65(1):55-61.

10- Meller I, Bickels J, Kollender Y, Ovadia D, Oren R, Mozes M. Malignant bone and soft tissue tumors of the shoulder girdle. A retrospective analysis of 30 operated cases. Acta Orthop Scand. 1997 Aug;68(4):374-80.

11- Bickels J1, Wittig JC, Kollender Y, KellarGraney K, Meller I, Malawer MM. Limbsparing resections of the shoulder girdle. J Am Coll Surg. 2002 Apr;194(4):422-35

12- Taira H1, Yoshida $S$, Takasita M, Tsumura $H$, Torisu T. Limb salvage for malignant bone and soft-tissue tumours of the shoulder girdle. Int Orthop. 2003;27(3):136-40.

13- Kiss J1, Sztrinkai G, Antal I, Kiss J, Szendroi M. Functional results and quality of life after shoulder girdle resections in musculoskeletal tumors. J Shoulder Elbow Surg. 2007 MayJun;16(3):273-9

14- Francis KC, Worcester JN Jr. Radical resection for tumors of the shoulder with preservation of a functional extremity. $\mathrm{J}$ Bone Joint Surg Am. 1962 Oct;44-A:1423-32

15- Kapoor S, Tiwari A, tumors around shoulder. International Orthopaedics (SICOT) (2008) $32: 829-834$ 